\title{
Analysis of Bull Sperm DNA Abnormalities Due to Cadmium Accumulation
}

\author{
Fuad Fitriawan \\ Institute of Islamic Studies Sunan Giri (INSURI) Ponorogo \\ J1. Batoro Katong No.32, Kertosari, Babadan, Kabupaten Ponorogo, Jawa Timur 63411 \\ Author correspondency: \\ fuadfitriawan@gmail.com
}

\begin{abstract}
Sperm abnormalities can occur by various causes. Abnormality of sperm is usually characterized by abnormal sperm motility and viability. This was caused by the inability of mitochondria on ATP-ase in producing ATP and ecto-enzyme Cik role in keeping the movement so that movement of sperm motility declines. Research that leads to total abnormal sperm DNA analysis is still rare. The purpose of this research was to get the results of the molecular characteristic picture of the overall characteristics of DNA loci that have abnormalities in bull sperm and get a picture of differences in overall DNA loci of abnormal and normal sperm. This research was conducted in October-December 2016. With the results of Group I consists of D, E with a percent similarity of 92.308\%, group II consists of C and Group I with a percentage similarity of $50.125 \%$, group II consists of A and B with a percent similarity of $100 \%$, group II and group III with a percentage similarity of $0 \%$. Based on the above data it can be concluded that the treatment $\mathrm{A}$ and $\mathrm{B}$ is not suspected to cause DNA damage compared to treatment C, D and E.
\end{abstract}

Keywords: Abnormality; Spermatozoa; Cow; PCR-RAPD; cadmium accumulation.

\section{INTRODUCTION}

Every family usually want to has offspring and feels happiness by the presence of baby in their family. But not all family get the dream to have offspring.

One of the things that led to the inability to continue its offspring is infertility that occurs on the husband and/or wife. According to Agritubella (2009) infertility is the inability of a couple to have children after intercourse regularly 2-3 times per week, without contraception for 1 year. In women, it is usually caused by an infection of the vagina, cervix disorders, abnormalities of the fallopian tubes and uterus according Muchtaromah (1999) besides female cause, the other $50 \%$ couple infertility contributed by male due to sperm abnormalities.

Previous research carried out by Fitriawan (2006) showed that sperm infertility largely caused by the sperm abnormalities that can occur due to wrong diet as well as abnormalities in male reproductive organs. The sperm abnormalities are usually marked with the limited ability of sperm in its motility and viability. Fitriawan[7] and Susilowati (2005) stated that it was caused by the inability of mitochondria on ATPase to producing ATP and enzyme ecto-CIK in keeping the movement according to Guven et al. (1998), sperm is said to be abnormal if it had more than $70 \%$ morphological abnormalities. Abnormality caused sperm mitochondrial deficiency that leads to failure in acrosome and post- acrosomal reaction so that sperm is unable to fertilize an egg.

Mature sperm has a length of approximately 50 micron, morphologically and functionally, sperm is divided into two parts, namely the head and tail (Destiany. M. 2007). According to Guyton and Hall (1997), the head of human sperm is oval shaped with a compact nucleus and few cytoplasm bit, Salisbury added that the head of the sperm chromatin contain materials that carry the DNA code to be transferred through pellucida zone of the ovum.

According to Fitriawan (2006) and Curry \& Watson (1995), biochemically, sperm abnormalities caused by the inability at the mitochondrial ATPase in producing ATP and enzyme ecto-CIK in keeping the movement so that the movement of sperm will decrease.

Research on the causes of infertility of sperm abnormalities in biochemical and physiological processes have been done, but a review of genetic and molecular studies have not been conducted. One method to determine molecular genetic picture of an organism-is by using PCR-RAPD method, which is a molecular technique to determine the overall picture of the characteristics of nuclear DNA and mitochondrial DNA which is made possible by the insertion, deletion, or substitution at restriction sites. According to Sutarno (2008), the advantage of PCR-RAPD method is that we can know the map of particular gene in an organism, and the state of these genes can be duplicated so that it seen more clearly. 


\section{MATERIALS AND METHODS}

This research was conducted by taking a sample of bull sperm from the Bali Cattle Center for Artificial Insemination Singosari Malang, which then will be treated for abnormality and PCR-RAPD analysis in the laboratory of Biochemistry and Molecular Biology Department, University of Brawijaya. The study was conducted from November to December 2016.

The equipments used in this study include a set of tools to handle the semen that consists of one unit of an artificial vagina, semen storage tube (test tube scale), a thermos of hot water and thermometer (for measuring temperature in a thermos). A set of tools to check the quality of the semen including test tubes, test tube rack, centrifuges, ose needles, waterbath, paper labels and a set of tools for observing sperm including a light microscope, object glass, cover glass, $\mathrm{CO}_{2}$ incubator, hand counter, a set of haemocytometer and tissue and a set of electrophoresis equipment.

The materials used for this study were as follows: Bali cattle semen samples, a set of semen material extraction, lysis buffer, protenase $\mathrm{k}$, potassium acetate, phenol, $\mathrm{NaCl}, \mathrm{CdCl}$, Vaseline, distilled water, chloroform isoamyl alcohol and isopropanol. Negrosineosin staining materials consist of a mixture of $0.3 \mathrm{~g}$ eosin, negrosin $0.5 \mathrm{~g}, 0.1 \mathrm{~g} \mathrm{Na}$ citrate, $10 \mathrm{ml}$ of distilled water and then in the stirrer with a temperature of 100 ${ }^{\circ} \mathrm{C}$. $500 \mathrm{ml}$ PBS consists of a mixture of $4 \mathrm{~g} \mathrm{NaCl}, 0.1 \mathrm{~g}$ $\mathrm{KCl}, 1.05 \mathrm{~g} \mathrm{Na} \mathrm{HPO}(\mathrm{H} \mathrm{O})$ and $0.1 \mathrm{~g}$ of KH PO.

The research of characteristic of DNA in abnormal sperm are reviewed by PCR-RAPD method which is a qualitative descriptive study of data images from PCRRFLP to be read in accordance with standard PCRRAPD analysis.

The technique of collecting data from this study was by random sampling, which is a technique that is done by taking samples directly on the ground which will then be treated to obtain abnormal sperm which will then be analyzed its abnormality using eosin staining and for further DNA examination using PCR-RAPD (Sutarno, 2008; Sarkar S, Hanry JB. 1996).

Data were analyzed using descriptive and qualitative analysis (Moleong, L. J. 1997) of sperm under light microscope and determined its quality, if $70 \%$ sperm are not normal then it is classified as abnormal sperm. Then, for further analysis, PCR-RAPD was performed to determine the polymorphism characteristics of DNA.

\section{RESULTS AND DISCUSSION}

Results of Total DNA electrophoresis on agarose $1 \%$ From the research, DNA eletroforesis of Bali bull sperm are shown in Figure 1. Qualitatively, there were differences between the control and treatment of DNA banding pattern. Thickness and thinness of the banding pattern will be the effect of treatment on the stability of sperm. In the sample A (control), almost 'total pattern of DNA bands appear not so visible but in treatment $(\mathrm{B}, \mathrm{C}$, $\mathrm{D}$, and $\mathrm{E}$ ) visible banding pattern shown very clearly.

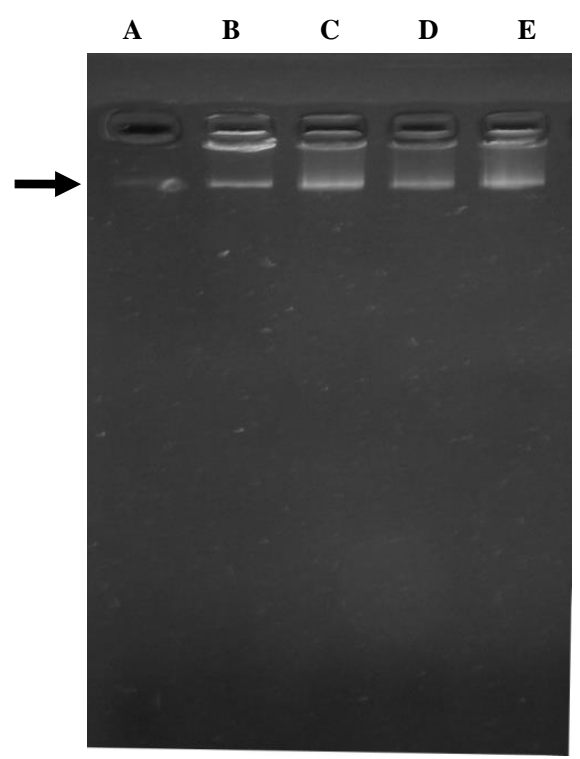

Explanation:

A : Control

B : Treatment of Cadmium Chloride 2 hours

C : Treatment of Cadmium Chloride 4 hours

D : Treatment of Cadmium Chloride 8 hours

E : Treatment of Cadmium Chloride Over night

Figure 1. Results of Total DNA electrophoresis on agarose $1 \%$.

According to Singer and Berg in Setyono, et al. (2008) a form of gene expression in organisms are protein and polypeptides which is formed through a series of processes of transcription and translation. Badel and Tatum in Setyono, et al. (2008) put forward a hypothesis about the relationship between genes and enzymes, that one gene-one enzyme which then evolved into one gene-one polypeptide. The assumption of the above changes that can lead to environmental change experiments in the process of transcription of different genes that can cause modifications even to cause mutations in the translation process, and can lead to the expression of different morphological structures. Mutations or changes at the gene level basically occur due to changes in the environment, so that the dynamics of different patterns of different DNA invaluable in detecting mutations in a timely fashioned (Toelihere. 1993).

Then from the qualitative data above can be seen in quantitative results as follows:

\section{Results of Quantitative measurements of total DNA sample of Bali Bull Sperm}

There is a less significant effect between treatments 0 hours to 2 hours, this is because the treatment process that may not have been so long that transcription of the DNA of spermatozoa has not shown any signs of abnormality. 
Table 1. Results of DNA Quantitative Measurement of total Sapi Bali.

\begin{tabular}{lllll}
\hline Samples & $\mathbf{A 2 6 0}$ & $\mathbf{A 2 8 0}$ & Levels $(\boldsymbol{\mu g} / \mathbf{m l})$ & Purity \\
\hline 0 hour & 0.004 & 0.002 & 100 & 2.0 \\
2 hour & 0.005 & 0.003 & 125 & 1.67 \\
4 hour & 0.005 & 0.003 & 125 & 1.67 \\
8 hour & 0.012 & 0.015 & 300 & 0.8 \\
Over night & 0.006 & 0.004 & 150 & 1.5 \\
\hline
\end{tabular}

The results of RAPD Sperm with Premiere OPA2 Bali Bull, 4 OPA and OPA 6

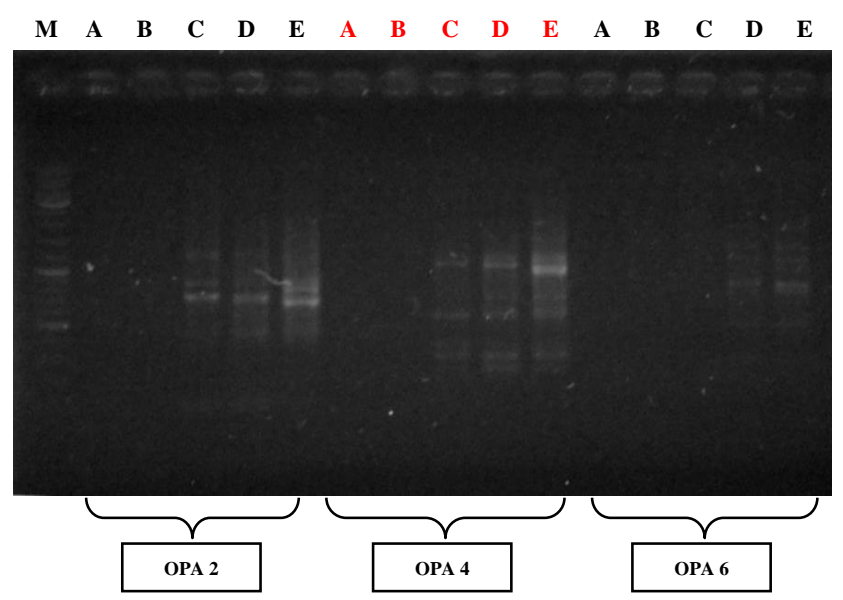

Explanation:

A : Control

B : Treatment of Cadmium Chloride 2 hours

C : Treatment of Cadmium Chloride 4 hours

D: Treatment of Cadmium Chloride 8 hours

E : Treatment of Cadmium Chloride Over night

Figure 2. Visualization of DNA produced by PCR-RAPD bull sperm on $1.5 \%$ agarose gel.

Then from the visualization of total DNA amplification process is carried out and replication that appear on the visualization of PCR-RAPD in Figure 2. From the image above, after analyzed by dendogram translation (Figure 3 ) method can be seen as follows:

\section{Dendogram RAPD analysis results using MVSP 3. Program 1 (Multivariate Statistics Package 3.1)}

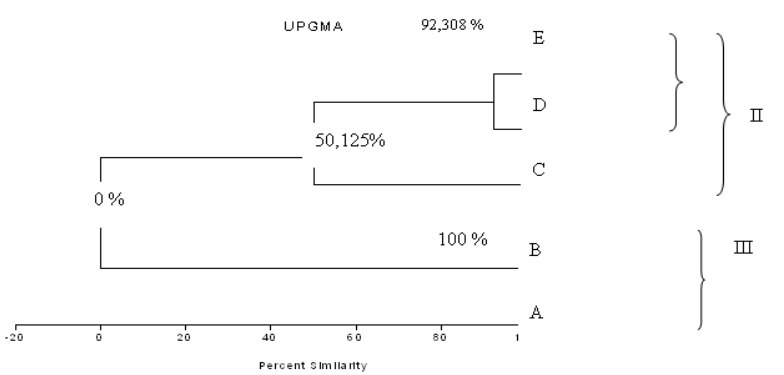

Figure 3. Dendogram of PCR-RAPD bull sperm with premiere OPA2, OPA4 and OPA6.
Based on the results of Bali bull sperm DNA amplification with a variation of the old treatment using a primer OPA2 cadmium, OPA4, and OPA6 showed that the highest percentage of sperm DNA damage treated with cadmium is composed of three groups:

a) The first group consists of $\mathrm{D}, \mathrm{E}$ with a percent similarity of $92.308 \%$

b) Group II consists of $\mathrm{C}$ and group I with a percent similarity of $50.125 \%$

c) Group II consists of A and B with the percent similarity of $100 \%$

d) Group II and Group III with a percent similarity of $0 \%$

If observed further from primer that has been used, it can be seen that the appearance of banding pattern in wells $\mathrm{A}$ and $\mathrm{B}$ almost non-existent, it is possible not to the effect of DNA damage by metal cadmium that has been given that at the time of 0-2 hours, but after the appearance of differences, there is already indications of changes in the physical and molecular of sperm.

According Destiany (2007) and Currt \& Watson (1995) that $\mathrm{Cd}$ in the cell is a non-essential subtance (a metal which is not needed by the body), if it settles in a cell, it will form $\mathrm{Cd} 2+$ that causes toxicity to the cell so that metabolism in the cells is inhibited which causes the generation of ATP as mitochondria will undergo changes drastically and immediately this is what causes the loci of genes on DNA changes.

Biochemically, according to Fitriawan (2006) sperm abnormalities caused by the inability to precisely at the mitochondrial ATPase in producing ATP and enzyme ecto-CIK role in keeping the movement so that the movement of sperm motility will decrease.The sperm DNA abnormalities can be seen physiologically using eosin $2 \%$ as follows:

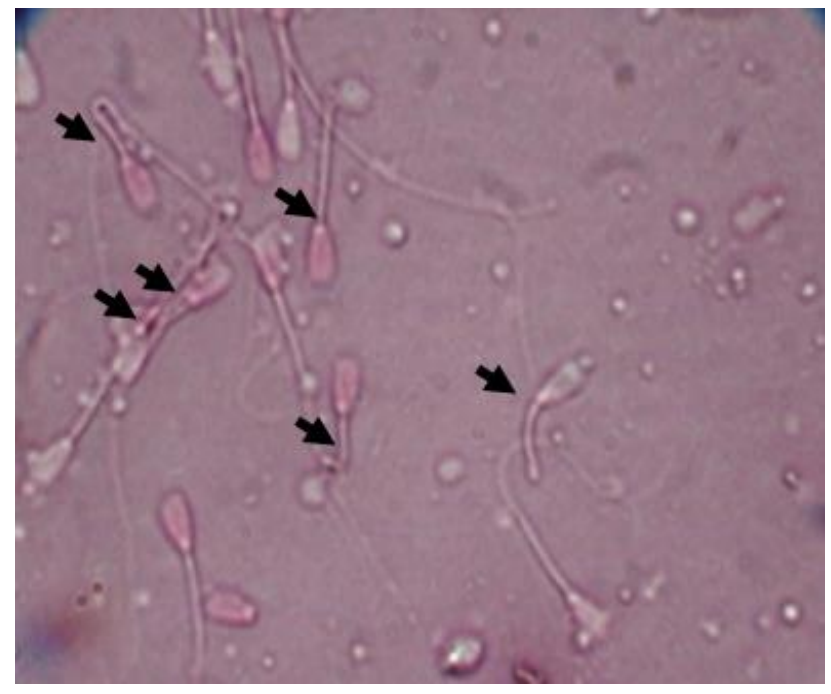

Description: $\rightarrow$ abnormalities of spermatozoa.

Figure 4. Sperm Abnormalities Conditions DCL treatment of $300 \mathrm{mg} / \mathrm{ml}$ 24 h. 
Sperm abnormalities were divided into 2 groups: primary and secondary abnormalities. Primary abnormality is an abnormality that occurs during spermatogenesis. Secondary abnormality is an abnormality that occurs due to environmental factors. The existence of sperm abnormalities in a certain amount (under 5\%) is a normal condition as a form of primary abnormality. A toxicant toxicity values against an organism can be expressed by several parameters, including the value of lethal concentration 50 (LC-50), a value of $50 \%$ of organisms causing death. From LC-50 we can assigned sub-lethal toxicity that resulted in damaging organ or disruption in growth, reproductive ability and behavior. Likewise, chronic toxicity, the effect is shown in a long time. In toxicant heavy metal, the last two things is very important, because the presence of heavy metals in water generally in a relatively low level but in the long term.

Abnormalities that occur in Figure 4 above in the form of abnormalities in sperm coiled tail, broken and bent, allegedly due to exposure to heavy metals cause the solution becomes hypertonic. If sperm are stored in a hypertonic solution will result in cytoplasmic vacuoles open and tail membranes become more permeable, so that the curled tail, until broken. The effect of this condition for fertility is a sperm motility will decreased, so the sperm cannot fertilized.

Based on the above data it can be concluded that treatment $\mathrm{A}$ and $\mathrm{B}$ allegedly did not cause DNA damage compared to treatment $\mathrm{C}, \mathrm{D}$ and $\mathrm{E}$.

\section{CONCLUSION}

From the research that has been done can be concluded that:

1. The first group consisting of D, E with a percent similarity of $92.308 \%$, Group II consists of C and group I with a percent similarity of $50.125 \%$, Group II consists of $\mathrm{A}$ and $\mathrm{B}$ with the percent similarity of $100 \%$, Group II and Group III the percent similarity of $0 \%$.

2. Treatment $\mathrm{A}$ and $\mathrm{B}$ (control) as a treatment for 2 hours allegedly did not cause DNA damage compared to treatment C, D and E.

\section{REFERENCES}

Agritubella, M. S. 2009. Infertilitas. Artikel kesehatan reproduksi http://situs.kesrepro.info/kb/referensi2.htm. Retrieved at 29 March 2010.

Coffee, C. J. 1998. Metabolism. 1st ed. Fence Creek Publising. Madison: $x$ iii $+454 \mathrm{p}$.

Curry MR, Watson PF. 1995. Sperm Structure and Function in: Graud zinkas JG, Yovich JL, (eds). Gametes-The Spermatozoon. Great Britain: Cambridge University Press. Pages 45-67.
Curry, M. R. \& Watson, P. F. 1995. Sperm Structure and Function. Great Britain. Cambridge University Press. Pages 45-67.

Destiany. M. 2007. Pengaruh Pemberian merkuri Klorida terhadap Struktur Mikroanatomi hati Ikan Mas. Thesis. Department of Biology Universitas Negeri Semarang

Fitriawan, F. 2006. Kemampuan Anti MPS dalam Menghambat Motilitas dan Viabilitas Spermatozoa Kambing, Domba, dan Sapi. Thesis Department of Biology Faculty of Science and Technology UIN Malang.

Ginzburg, SA, 1972. Fertilization in fishes and the problem of polyspermy. Wiener Bindery. Jerussalem.

Guven, M. C., Can, B., Saran, Y. 1998. Ultrastructural Changes in the Spermatozoa of Infertil Man. Journals from dept. histology-embriology, medical School of Ankara University Turkey.

Guyton AC, Hall JE. 1997. Buku Ajar Fisiologi Kedokteran. Diterjemahkan oleh Irwati S, LMA Ken Ariata T, Alek S. Jakarta: Penerbit Buku Kedokteran EGC. Pages: 309-314.

Hafez, E.S.E. 1977. Techniques for Improving Reproduction Efficiency, pp.455-479. The CV Mosby Company: St. Louis.

Mason, CF. 1981. Biology of Freshwater Pollution.Longman Inc, New York.

Moleong, L. J. 1997. Metodologi Penelitian Kualitatif. Bandung, P.T. Remaja Rosda Karya.

Muchtaromah, B. 1999. Pengaruh Pemberian Metoklopramid terhadap gambaran Histologis Testis Tikus Putih (Rattus norwegicus). Thesis Postgraduate Program Department of Bioreproduksi UNAIR Surabaya.

Nelson, RW. 2003. Morphology of Normal and Abnormal Canine Spermatozoa. Couto CG. Journal of Small Animal Internal medicine. Mosby

Partodiharjo, Soebadi, 1992. Ilmu Reproduksi Hewan. Mutiara Sumber Widya. Jakarta Pusat. Cetakan ke III Pages 523-531.

Rijnders PM. 1996. The Spermatozoon-Theory. In: Brass JW, et al. Editors. IVF lab-laboratory as pects of in vitro vertilization. NV Organon. Pages 23-39.

Salisbury, G. W. 1985. Inseminasi Buatan Pada Sapi. Gadjah Mada University Press Yogyakarta.

Sarkar S, Hanry JB. 1996. Andrology Laboratory and fertility Assessment, in: Henry JB, Editors. Clinical Diagnosis and Management by Laboratory Metods. Philadelphia.

Setyono, P., Soetarto, E. S., 2008. Biomonitoring Degradasi Ekosistem Akibat Limbah CPO Muara Sungai Mentaya Kalimantan Tengah dengan Metode Elektromorf Isozim Esterase. Jurnal Biodiversitas Vol 9. Nomor 3. Universitas Sebelas Maret Surakarta. Pages 232-236.

Sutarno, 2008. Diktat Materi Bioteknologi dan Seluler. Faculty of Mathematics and Natural Sciences Universitas Sebelas Maret Surakarta. Pages. 35-40.

Susilowati, T. 2005. Fisiologi Spermatozoa: Kapasitasi, reaksi Akrosom dan Fertilisasi. Faculty of Animal Husbandry Universitas Brawijaya Malang.

Toelihere. 1985. Fisiologi Reproduksi pada Ternak. Publisher Angkasa Bandung. Pages $93-115$.

Toelihere. 1993. Analisis Kualitas Semen pada Ternak. Publisher Angkasa Bandung. 